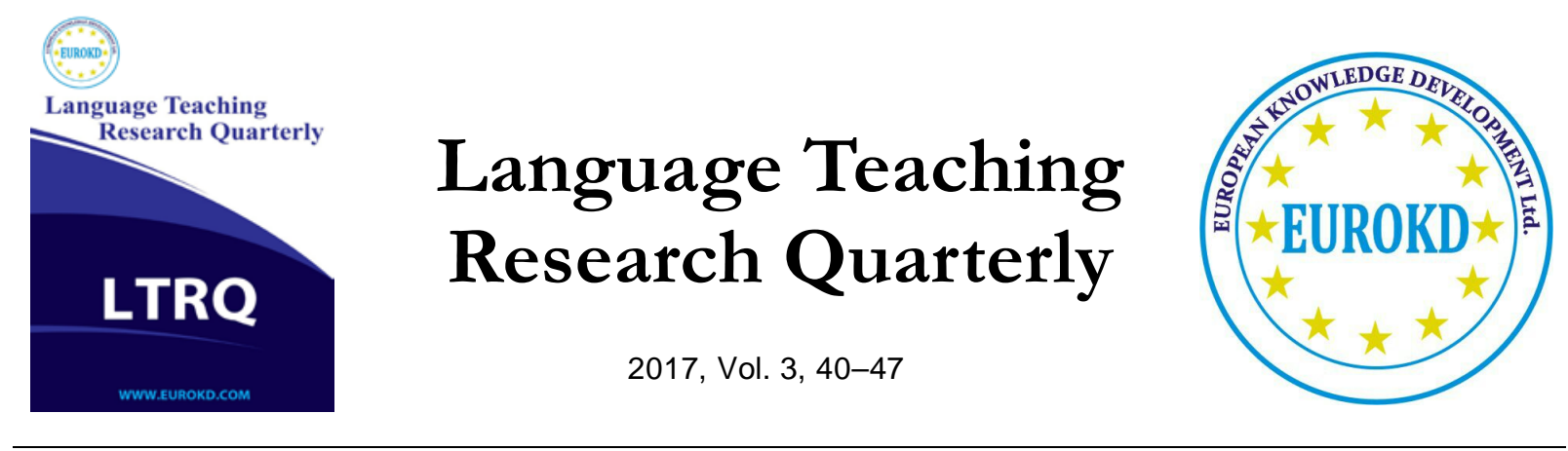

\title{
On the Relationship between Persian EFL Teacher's Discourse and Language Learning Anxiety
}

\author{
Mehrnoosh Eslami i, ${ }^{1,}$, Mahmoud shaker ${ }^{1}$, Fatemeh Rakhshandehroo ${ }^{1}$, \\ Mohammad Ali Izadpanah² \\ ${ }^{1}$ University of Applied Science and Technology, Shiraz Khabar Media School, Shiraz, Iran \\ ${ }^{2}$ Shiraz University, Shiraz, Iran
}

\begin{abstract}
Received 3 July $2017 \quad$ Accepted 27 September 2017

The present study was an attempt to investigate Persian EFL teacher's discourse and its relation to learners' language learning anxiety. It was carried out in a bilingual elementary school and a language institute. The participants included students between the ages of 9 to 15 who studied English at least for three years in Shiraz, Iran. Data was gathered through a forty-minute audio-recording lesson during regularly scheduled class time and semi-structured interviews. The result indicated that there is a significant relationship between teacher's discourse and learners' anxiety. Moreover, the teachers' discourse in immersion education was found to be more significant than the ones in non-immersion programs. The obtained result of this study is to familiarize teachers with the importance of appropriate language use in EFL classroom and how such language use in the classroom can be improved through video and audio recording of their lessons.
\end{abstract}

Keywords: Immersion Programs, Non-Immersion Programs, EFL Teacher Discourse, Language Learning Anxiety.

\section{Introduction}

Generally speaking, anxiety is a troublesome feeling in every one's mind. As Horwitz (1986) mentioned, anxiety is a subjective feeling of tension, apprehension and worry that is associated 
with arousal of the automatic nervous system. According to MacIntyre \& Gardner (1994a) anxiety is "the feeling of tension and apprehension specifically associated with second language contexts" (P.284). One of the controversial issues of foreign language researchers was the negative effects of foreign language anxiety (FLA) as an affective factor on language learning (Kunt \& Oztas Tum, 2010). FLA is "a distinct complex of self-perceptions, beliefs, feelings, and behaviors related to classroom language learning arising from the uniqueness of the (foreign) language learning process” (Horwitz et al., 1986, p. 128).

Anxiety makes several problems for foreign language students since it may interfere with the acquisition, retention and production of new language (MacIntyre \& Gardner, 1991). Other related problems reported by Oxford (1991) are self-esteem and self-confidence reduction, decreasing of risk-taking ability, and in general hampering proficiency in the second language which may occur in foreign language learners if they have serious language anxiety. Most recent studies have consistently yielded negative correlation between L2 anxiety and L2 achievement or proficiency (e.g. MacIntyre \& Gardner,1994a \& MacIntyre, Noel \& Clement, 1997; Aida, 1994; E.K. Horwitz, M.B. Horwitz \& Cope, 1986; Bailey, 1983; MacIntyre \& Gardner, 1991; Coulombe \& Roberts, 2000; Gardner,2005; Samimy \& Tabuse, 1992; Saito \& Samimi, 1996; Philips, 1992; Young, 1991; Cample \& Oritz, 1991; Powell, 1991; Crookal \& Oxford, 1991).

There exist lots of things in the classroom that may lead to EFL learner's anxiety, for instance, Social Status, Power Relations, Sense of Identity, Errors in Social Setting (Tanveer, 2005) and teacher's behavior and their discourse. Among these factors and much more, teacher's talk is a really important factor in increasing students' motivation and decreasing their anxiety. One study done by Görsev Inceçay (2010) represented that teachers need to be aware of the recent teaching approaches to minimize the obstruction of their talk in young learners' learning process. In countries such as Iran, in which we can see classes which are running through teacher centered method and teacher has a very notorious role in education, teachers must be an important factor in students' achievement. Achievement occurs better if affective variables such as anxiety diminished to a large extent in the class. (MacIntyre \& Gardner, 1994 a \& b). Therefore, teachers in these contexts as the basic role of learning should diminish such an affective variable. One of the ways to do so is using a manageable discourse. In other words, they way each teacher speaks in the class, answers student's question, gives them feedback or even the way he or she talks during his or her teaching material can lead to or remove students' anxiety. On the whole, on account of the importance of teacher's talk on removing student's anxiety, further research in this area should open the door to teacher's talk and its relation with learner's anxiety.

\section{Review of literature}

Teacher talk

As Nunan (1991) points out, "Teacher talk is of crucial importance not only for the organization of the classroom but also for the processes of the acquisition.” Teacher talk is also regarded a factor of success or failure in classroom teaching. (Hakansson, cited from ZhouXing and Zhou Yun, 
2002). Teacher talk has lots of features and most of the researches in this regard were appointed on these features. Among them, the feature of teachers as a facilitator is the most important one.

Facilitator talk is an alternative to the teacher-fronted classroom (Clifton, 2006). Cullun (2002) mentioned another important feature which is supportive teacher talk. Cullun states the importance of follow-up and feedback in the learning process. Walsh (2002) believes that teachers construct or obstruct learner participation and learning in classroom through their choice of words.

On the other hand, Brazil and Sinclair (1982) in their book state that the initiation - response - follow-up pattern of classroom interaction is the main characteristic of teacher talk. However Clifton (2006) strongly opposes this feature since he believes student is disempowered through it. He argues that in this way it is a teacher who controls the speech of students and denies the students responsibility for directing the lesson which is the result of traditional teaching methods.

\section{Language anxiety}

One of the important roles of language learning is anxiety. Anxiety is defined as "the subjective feeling of tension, apprehension, nervousness, and worry that is experienced by an individual" (Spielberger, 1975, p.5). Language anxiety also defined as "the feeling of tension and apprehension specifically associated with second language contexts” (MacIntyre \& Gardner, 1994a, P.248).

In the past two decades a great deal of research into second or foreign language anxiety has been done which lead into three types: State, trait and situational. (MacIntyre \& Gardner, 1991).

State anxiety is the apprehension that a person experiences at a particular moment in time as a response to a definite situation. (Chastain, 1976; Kleinmann, 1977; Young, 1986). Trait anxiety is a relatively stable personality trait and is based on the assumption that an individual exhibits anxious feeling in every situation. (Spielberger, 1975). A third type of anxiety is situation specific anxiety, which refers to the anxiety experienced in specific situation or context. (Spielberger, Gorsuch \& Lushene, 1970).

Evidence shows that language learning anxiety is different from other forms of anxiety. Research in to language learning anxiety indicated that language learning can be situation specific (Horwitz, 2001) and is unique to FL classroom. "FLA is communication apprehension in a foreign language context and has been identified as one of the major obstacles to acquisition and fluent production of foreign language" (Dewaele, Petrides \& Furnham, 2008, p.911). In general most of the studies confirmed the negative correlation between FL anxiety and achievement (MacIntyre \& Gardner,1994 a \& b; MacIntyre, Noel \& Clement, 1997; Aida, 1994; E.K. Horwitz, M.B. Horwitz \& Cope, 1986; Bailey, 1983; MacIntyre \& Gardner, 1991; Coulombe \& Roberts, 2000; Gardner,2005; Samimy \& Tabuse, 1992; Saito \& Samimi, 1996; Philips, 1992; Young, 1991; Cample \& Oritz, 1991; Powell, 1991; Crookal \& Oxford, 1991).

As it was mentioned above, anxiety should be diminished to the extent possible in order to lead learners to achievement in language learning and as it was mentioned, teacher talk or teacher's discourse can be a factor in creating anxiety in learners. For this end, the researcher want to 
evaluate discourse of some Persian teachers to see whether teachers talk has any influence on removing or creating learner's anxiety and answer the following questions:

1. Is there any relationship between teacher's discourse and learner's Anxiety?

2. Is there any significance difference between teacher's discourse in immersion education and non-immersion programs?

\section{Methodology}

Participants

This study will be conducted on 117 male students of 10 years old in Immersion School and 115 female students of about 9-11 years old in language learning institutes in Shiraz who were studying English at least for two years. All of the students were learning English as a foreign language. None of them had contact with the relevant target language community. The exposure time to English for each student was the same. They were all pre-intermediate level students.

\section{Instruments and data collection procedure}

With the permission of each single teacher and school/institute officials, the data was gathered through a forty-minute lesson audio-recording during 16 regularly scheduled class time. The teacher was given a guideline that audio-recorded part of the lesson should contain an activity with examples of teacher-learner interaction. To gain information on the participants' in-depth thoughts and experiences, the researchers observed six randomly selected classrooms in each program and also invited six teachers and 30 students from both programs to take part in semi-structured interviews. Each interview lasted about 15 min and included a list of open-ended questions that allowed flexibility.

\section{Data analysis procedures}

For the purpose of the study, data will be collected from the above-mentioned source which will be analyzed by means of Conversation Analysis Methodology.

\section{Results and Discussion}

Interviewing Students from Bilingual Schools

The results on the views of students in the immersion program concerning the teacher's talk are given here. These students were in fifth grade and they had spent their entire elementary school educational life in the same bilingual school. They had never participated in any other institutes except the bilingual school they were currently studying at. Regarding the questions they were asked about their attitude toward the immersion program and how their teacher's talk can influence their learning, one of them mentioned; "the atmosphere presents in my class is unbelievably fun and pleasurable. This is my best time during the day".

Moreover, another student said that "I have never had any experience of having stress in my English classes and it is very surprising for me how I have learned English so easily". The most important factor students talked about was the teachers. One of them said that "I have a fun time 
with my classmates and my teacher. My teacher always uses some sentences that make us be fresh and active; I like my teacher very much."

In terms of their attitude toward their teacher's talk in case of having anger, one of the students mentioned that "I don't know what she does that although I am scared of her in some situations, she is still kind using amazing words".

\section{Interviewing Students from Language Institutes}

Most of the students were 9 to 11 years old and they had the experience of learning English for at least two years. However, some of them studied in the same institute but some others had tried two or more institutes. In terms of their attitude toward the language institute and how their teacher's talk can influence their learning, one of the students stated that "studying English is really hard especially when it interferes with my school hours and my teacher starts to advise us instead of understanding my feelings."

Regarding their attitude toward their teacher's talk in case of having anger, a student said that "it is really hard for me to forget some of my teacher's comments which makes me to have the feeling of nervousness". Other student mentioned that "knowing not being able to answer the questions and my teacher's comment as a result is a big stress for me in the class". Yet there were some students who believed that their teacher's talk is very helpful and motivated them in learning English better and stated that there is no stress with them in the class.

By asking them some everyday questions, the interviewer found the differences between the two groups which will be discussed here. Based on the findings generated from the interviews of students in immersion program, the reasons behind the interviewees' favorable attitudes toward the teacher's talk can be summarized as follows:

1. The teachers in immersion programs had pre-planned discourse.

It was believed that students had no stress just because the teachers were consciously using words which were motivative and provided a free stress condition for learning. Moreover, the teachers were trained to use specific comments for students' activities which were all positive even in cases in which the result is not that much pleasing.

2. Teachers in immersion programs pay attention to simplicity their words while teaching.

Since teachers in immersion program have to teach difficult items of science, math and social studies, it is a crucial point for them to practice their talks before class. Moreover, having one head master in each grade helped teachers to be more prepared in this regard. In contrast, in language institute, the only guide of teacher's talk while teaching was the teacher's books which cannot be the same as their counterpart's teachers of immersion programs.

3. It helps learners to become more autonomous in learning

Both the students and teachers believed that everyday exposure of students to a foreign language in an English-speaking environment helps them be more autonomous in their learning process. 
Furthermore, students' assertion on using the language and also understanding the others' speech in English signifies the student's ability in listening comprehension, vocabulary and grammar. At the same time, students' interest in reading short stories and receiving textbooks as a present was considered as further emphasis on how such schools are able to improve the student's ability in regard to reading English texts. It was believed that students would learn the skills integratively although each skill was basically focused on separately.

The results taken from the interviews of students in language institutes shed light on the differences that existed between the language institutes and immersion programs. One of the most outstanding differences found between the results of the two groups was the lack of attention to the affective aspects of language learning in language institutes. In other words, some of the teachers believed that although they were careful about such factors, due to the limitation of time they focused only on teaching language skills without paying that much attention to the words they use to reach this end. Moreover, most of the time, several students were so much mentally involved in the horror of receiving bad comments from their teachers that such a fear could impede their ability in comprehending and retaining the language material to which they were exposed in the best manner possible. Another advantage of immersion program over language institutes was the atmosphere of their class which was greatly dependent on the teacher's behavior and discourse. However, this understanding did not exist in language institutes as far as the students asserted that they were annoyed by the comments they may get each session.

The analysis of the audio tape recording also proved that teachers in immersion program were really conscious in using some specific terms both verbally and non-verbally which made students relax and hence could control the factor of stress in the class. In contrast, several situations were seen that teachers in language institutes unconsciously used words that could affect on specific types of students. Moreover, the teachers' comments were mostly one-word comments which was totally different from immersion program teachers where full comments including u positive and motivate words were used.

The present study is significant in this way that having stress and anxiety not only lead learners to quit their study or demotivate them on learning, but also decrease their self-esteem and selfconfidence in using the language outside the classroom. It is very important for each teacher to be aware of this important factor that how their discourse can affect their students in a way that can remove or increase their anxiety. Therefore, this study wants to aware teachers how they can control their discourse in a way that can make the relationships of their students with themselves in a close and intimate manner and remove stress and anxiety from them by preparing a comfortable environment for them. In short this study will,

1. Aware teachers about the importance of appropriate language use in EFL classroom.

2. Help teachers to find out their language use in the classroom by the help of video and audio recording of their lessons.

4. Aware Iranian's teacher to devote more time and attention to teacher talk in the classroom.

\section{Conclusion}

www.EUROKD.COM Doi: 
The present study tried to investigate the importance of teacher's discourse in the class and compare students amount of anxiety in two different programs of immersion and language institutes. To this end, audio-taped recording and interviews were made use of. The results revealed that there was a significant difference between student's anxiety in the two programs. Furthermore, the results indicated that the observed classrooms in both programs differed in the way teachers comment on student's homework. The study indicated that the teachers in immersion program were conscious in using their discourse and they were all trained in this regard. Therefore, more attention is needed for teachers to prepare themselves before going to their classes. In conclusion, it can be safely claimed that in general, students in immersion programs had less amount of anxiety than students in language institutes.

\section{References}

Aida, Y. (1994). Examination of Horwitz, Horwitz, and Copes's construct of foreign language anxiety: The case of students of Japanese. The Modern Language Journal, 78,155-178.

Brail, D., \& Sinclair, J. (1982) Teacher Talk. Vol.60 Oxford: Oxford University Press p 142.

Campbell, C. \& Ortiz, J. (1991). Helping students overcome foreign language anxiety: a foreign language anxiety workshop. In E.K. Horwitz \& D.J. Young, (Eds.). Language Anxiety: From Theory and Research to Classroom Implications (pp.153-168). Englewood Cliffs, NJ: Prentice Hall.

Chastain, K.D. (1976). Developing second language skills .Chicago: Rand McNally.

Coulombe, D., \& Roberts, W.L. (2000).The French as a second language learning experience of Anglophone and Anglophone University students. Journal of international migration and integration, 2(4), 561-571.

Crookall, D., Oxford, R. (1991). Dealing with anxiety: Some practical activities for language learners and teacher trainees. In: Horwitz, E.K., Young, D.J. (Eds.), Language Anxiety: From Theory and Research to classroom Implication (pp.141-150). Prentice hall, Englewood Cliffs, NJ.

Cullen, R. (2002) Supportive teacher talk: the importance of the follow-up in English language teaching. Vol.53. Oxford: Oxford University Press pp.117

Dewaele, J.M., Petrides. K.V \& Furnham, A. (2008). Effects of trait emotional intelligence and sociobiographical variables on communicative anxiety and foreign language anxiety among adult multilinguals: A review and empirical investigation. Language learning, 58(4), 911-960.

Gardner, R.C., (2005). Integrative Motivation and Second Language Acquisition. Retrieved July 31, 2009 from http://publish.uwo.ca/wgardner/caaltalk5final.pdf.

Görsev Inceçay (2010). The role of teacher talk in young learners' language process. Procedia Social and Behavioral Sciences. 2 .277-281.

Horwitz, M.B. \& Horwitz, E.K. \&Cope, J.A. (1986). Foreign language classroom anxiety. Mondern Lanugage Journal, 70(2), 125-132.

Horwitz, E (1986). Preliminary evidence for the reliability and. Validity of a foreign language .TESOL Quarterly, 20, 559-62.

Kleinmann, H. (1977).Avoidance behavior in adult second language acquisition. Language learning, 27, 93-107.

Kunt, N \& Oztas Tum, D. (2010). Non-native student teachers' feelings of foreign language anxiety. Procedia Social and Behavioral Sciences, 2. 4672-4676.

MacIntyre, P. D., \& Gardner, R. C. (1991). Methods and results in the study of anxiety and language learning: A review of the literature. Language Learning, 41, 85-115. 
MacIntyre, P.D., \& Gardner, R.C. (1994a). The subtle effects of language anxiety on cognitive processing in the second language. Language Learning, 44, 283-305.

MacIntyre, P.D., \& Gardner, R.C. (1994b). The effects of induced anxiety on three stages of cognitive processing in computerized vocabulary learning. Studies in Second Language Acquisition, 16, 1-17.

MacIntyre, P.D., Noels, K.A., \& Cle'ment, R. (1997).Biases in self-ratings of second language proficiency: the role of language anxiety. Language Learning, 47, 265-287.

Nunan, D. (1991) Discourse Analysis for Language Teachers. Cambridge: Cambridge University Press.

Powell, J.A.C., 1991. Foreign language classroom anxiety: Institutional responses. In: Horwitz, E.K., Young, D.J. (Eds.), Language anxiety: From Theory and Research to Classroom Implication (pp. 129-140). Prentice Hall, Englewood Cliffs, NJ.

Saito,Y., \& Samimy, K. K. (1996). Foreign language anxiety and language performance: A study of learner anxiety in beginning, intermediate, and advanced-level college students of Japanese. Foreign Language Annals, 29, 239 -251 .

Samimy, K.K., \& Tabuse, M. (1992). Affective variables and a less commonly taught language: A study in beginning Japanese classes. Language Learning, 42, 377-398.

Spielberger, C., D. (1975). Anxiety: State, trait, process. Washington D. C.: Hemesphere /Wiley.

Spielberger, C.D., Gorsuch, R.L. \& Lushene, R.E. (1970). The state-trait anxiety inventory: test manual for form X.Palo Alto. California: Consulting pscychological Press.

Tanveer, M. (2007). Investigation of the factors that cause language anxiety for ESL/EFL learners in learning speaking skills and the influence it casts on communication in the target language. Unpublished dissertation, University of Glasgow.

Walsh, S (2002) Construction or Obstruction: teacher talk and learner involvement in the EFL classroom. Language Teaching Research 6/1 pp.3-23

Young, D. J. (1991). Creating a low-anxiety classroom environment: What does language anxiety research suggest? The Modern Language Journal, 75, 426 - 439. 